\title{
TRAINING FOR SMART INTERNET WOMEN AMONG KOTAKU WOMEN'S CADRES IN KELURAHAN ARJUNA, BANDUNG - WEST JAVA
}

\author{
Dwi Ajeng Widarini \\ Prof. Dr. Moestopo (Beragama) University \\ ajengsastroprawiro@dsn.moestopo.ac.id
}

\begin{abstract}
Women as the first source of information in their families need to understand the internet access as a source of information. The rises of hoax information, negative effects from internet use and the influence of internet in educating children are the purpose of training for smart internet women. This training is conducted by lecturing method, sharing and practice of using social media. It is expected that with this training women can use the internet to improve their quality of life, prevent the spread of hoaxes and have the skills to become parents in the digital era.
\end{abstract}

Keywords: Hoax, digital literacy, internet

\section{INTRODUCTION}

Women as the first source of information in the family have a very important role for their social environment. The capacity of women to absorb information and re-convey it becomes central. The use of information technology, in this case the internet as access to information for women, becomes something new. Access to information via the internet that is not limited to time and distance improves women in gaining knowledge that can affect their immediate environment, especially their families.

The development of the communications industry facilitates unlimited communication. Tapscott (2008) says "If you understand the Net Generation, you will understand the future" (Budiargo, 2015: 21). By understanding the generation in the era of digital revolution, we can understand the future especially in understanding the processes of unlimited human communication and interaction.

Based on the Survey on Indonesian Internet User's Penetration and Behavior conducted by APJII in 2017, female internet users accounted for $48.57 \%$ of 143.26 million internet users in Indonesia. This number will continue to increase in accordance with the development of information technology infrastructure in Indonesia. The internet is a medium of communication for women to gain knowledge, new information, express opinions and drive the economy.

Despite having a good increase in the number of women accessing the internet, the access of women to adopting knowledge about the internet and its use in improving the quality of life is still lacking. One of the obstacles is that women often do not have the opportunity to develop their potential in the use of technology. In Triastuti, (Women's Journal, 78: 2013) a number of studies on women's participation in online activities, it is due to the attitude of women who are nervous (Yasen, 2013), and a sense of insecurity when working using computers or the internet (Tsai and Wu, 2006: Donatet .al., el). The ability of women to access information technology needs to be improved in addition to increasing women's capacity; this is also useful to prevent the dissemination of hoax information through social media.

Based on We Are Social, 57.2 million are female Facebook users in Indonesia. The use of Facebook, Instagram, WhatsApp and other social media applications, on the one hand opens access to information but on the other hand it can have negative effects such as the blades that have to be used wisely.

Digital literacy understanding among housewives with a lower middle economic background needs to be done in order to improve the understanding of internet use. Digital literacy in Glister (1997: 2 ) is the ability to access computer networks and use them. Digital literacy is the ability to understand 
and use information in a variety of different formats and sources displayed on a computer screen. Users not only understand how to get information but also how to use that information to improve their quality of life.

Based on research on the Digital Literacy Movement Map in Indonesia studying the actors, variety of activities, target groups and partners, data on target groups of digital literacy activities in a number of cities in Indonesia are collected. Group of students/teenagers is $(29.55 \%)$, college students $(18.5 \%)$, the general public $(15.22 \%)$, parents $(12.23 \%)$, teachers and lecturers $(10.14 \%)$. The remaining targets are mass organizations, NGOs, government, and the media, with a portion of $6.86 \%$. Although there is no specific information on the number of female or male parents in this data, but at least it can describe that the percentage of parents who are in a group in digital literacy activities is not high.

This needs to be followed up because parents in this case female parents need to be given digital literacy training. The digital immigrants must have the provision of knowledge in order to provide guidance and conduct guidance for children in accessing the internet.

Discussing about improving the quality of life by accessing the internet, especially among women in urban and sub-urban areas is the reason for the importance of doing digital literacy. The development of hoax information in the fields of health, education and other social events makes women vulnerable victims. Based on this thought, it is necessary to conduct digital literacy activities among KOTAKU (City without Slums) cadre women in Desa Arjuna, Bandung, West Java.

This activity is one of a series of community service activities carried out in three places, Kelurahan Grogol-Jakarta, Serpong-Banten and Kelurahan Arjuna-Bandung. The activity which was initiated by Indonesia Voice of Women was collaboration with Fikom UPDM (B), Chevening Alumni Association and British Embassy. By involving Chevening Alumni and the three founders of Indonesia Voice of Women, Karlina Octaviany, and Citra Indah Lestari and Fikom UPDM (B), Dwi Ajeng Widarini (Fikom UPDM (B)), and involving Dr. Eni Kardi Wiyati, Cakra Ningsih, M.Ikom and volunteers from students of Fikom UPDM (B).

\section{METHOD}

The method of implementation was lectures for 2 times and mentoring to produce contents through social media. The first workshop was held on 28 October 2017 and the second was on 13 January 2018. The implementation of the activities included (1) Lectures; (2) Playing the flow of communication and (3) sharing about using the internet and building activities with children to create positive contents, (4) mentoring through WhatsApp group.

\section{RESULT AND DISCUSSION}

Women as part of the information society must be given space to adopt the benefits of the internet to improve their quality of life. Through this training, KOTAKU women cadres were given an understanding of the internet and internet information that must give a positive impact on women.

The first thing to do in this training process was that the participants were given a questionnaire, to find out the benefits of the internet they used. Most of the participants used the internet as a means of getting information and making friends. In addition, some participants already knew the meaning of hoax information, but in conducting the selection process for hoax information, there were obstacles due to participants' ignorance about how to verify the information.

As a simulation to find out how the hoax information was delivered, the "information radius" game was performed. This game illustrated the chain information delivery process that was often distorted by information that is lacking or added at the time of delivery.

Through this simulation, participants were invited to think critically when getting information on social media. The use of search engines by participants was not used in the process of verifying data and facts they obtained through social media; this was due to their ignorance of the function of the data search engine. In this training, they were guided to use their smart phones and search for data search engines in their applications. By using key words, the participants finally learned how to use and verify information, images and videos by using an application on social media or the google.com data search engine. 
The selection process of information obtained on the internet is important to be done through the use of applications. In addition, participants were also informed about the patterns of writing hoax information that are often circulated in the community, this is important so that participants can detect early which information is correct and accurate. Further, it also took precautions and reminded to prevent the spread of hoax information.

Moreover, often the information presented through social media is delivered by people who are believed to have credibility so they are easily trusted by the message recipients. This pattern of behavior makes it easy to spread hoaxes which ultimately have a negative impact on women. The process of checking and checking the information is important, even if the information is obtained from people who have credibility or community leaders.

In addition to providing knowledge about hoaxes and ways to prevent its spread, the participants were also invited to create positive contents on their social media. Some participants, who were involved in entrepreneurship, have not increased the capacity to use social media for socialization about their business. Through this training, they were invited to create a fan page on their Facebook accounts to introduce their businesses and make good photos to download on their accounts. The result is that some participants were able to inform about the entrepreneurship they had through social media.

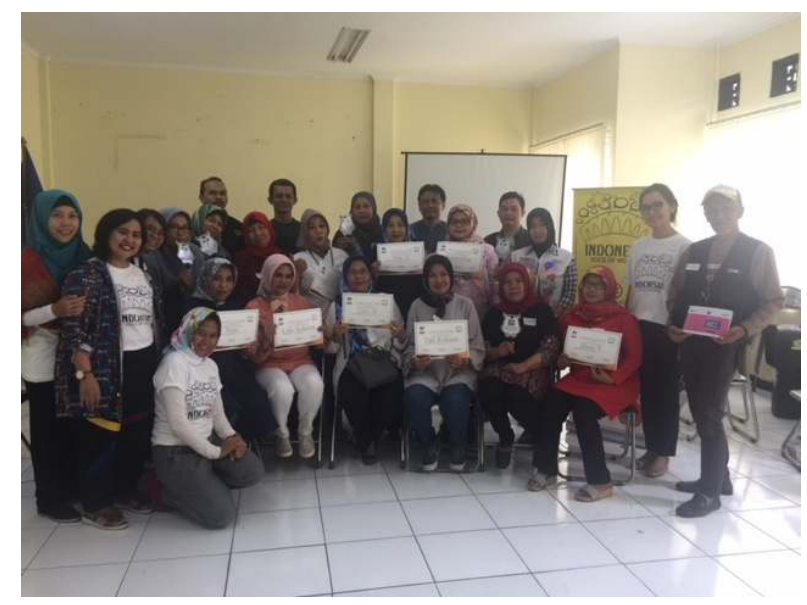

Figure 1. PKM Activity in Kelurahan Arjuna, Bandung

The existence of the internet which has an impact in the communication process between children and parents was also observed in this training. Participants shared what their obstacle was in communicating with children, especially regarding the use of social media and the internet. Participants experienced concerns as a result of the use of social media by their children. However, due to limited information and knowledge in the field of technology, they tended to allow online activities by their children. Supervision of children's activities, especially those who are underage, needs to be done; therefore sharing was also presented on how to process effective communication between children and parents, and how to use the internet.

In this training, the participants were invited to discuss on the topic about communicating with children and provide suggestions for activities to create contents with children. It is expected that with the method of making contents with their children, parents and children can publish positive contents together.

After the training, the participants established communication with the facilitators and speakers through WhatsApp group, this was to follow up the information needs for the participants to ward off hoaxes and answer questions about the use of social media for improving quality of life. In addition, a competition was held to create positive contents and won by one of the participants from Kelurahan Arjuna. 


\section{CONCLUSIONS}

Women have the potential as the first source of information in the family, decision makers, driving the economy and educating their families. The existence of the internet opens opportunities for women to increase their role in public activities with the use of the internet. Digital literacy training for women, especially among housewives with a lower middle economic level must be carried out in a sustainable manner in order to increase women's capacity as a driver of progress.

Collaboration in the implementation of PKM is something that needs to be done continuously, besides that the topic of issues raised in this PKM can also increase public awareness of digital use and prevent hoaxes from arising.

\section{ACKNOWLEGEMENT}

The author would like to thank the leader of the Faculty of Communication Studies UPDM (B), KOTAKU, Chevening Alumni and British Embassy who provided support to us in carrying out community service.

\section{REFERENCES}

Bugiardo, D. (2015). Berkomunikasi ala Net-Generation. Elex Media Komputindo.

Gilster, P., \& Glister, P. (1997). Digital literacy. New York: Wiley Computer Pub.

Gumilar, G., \& Kusmayadi, I. M. (2018). Instagram Usage by "Barstrad" Community in Bandung CityWest Java. Jurnal Komunikasi Ikatan Sarjana Komunikasi Indonesia, 2(2), 65-70.

Indonesia, P. (2016). Infografis Penetrasi dan Perilaku Pengguna Internet Indonesia. APJII, Jakarta.

Kurnia, N., \& Astuti, S. I. Peta Gerakan Literasi Digital Di Indonesia: Studi Tentang Pelaku, Ragam Kegiatan, Kelompok Sasaran Dan Mitra Yang Dilakukan Oleh Japelidi. Informasi, 47(2), 149166.

Maryani, E. (2018). Developing Social Solidarity through Digital Media. Jurnal Komunikasi Ikatan Sarjana Komunikasi Indonesia, 3(1), 12-17.

Puspitasari, P. (2018). Binary Opposition in Narrations of "Native" in Social Media. Jurnal Komunikasi Ikatan Sarjana Komunikasi Indonesia, 3(1), 28-35.

Tarigan, R. E. (2018). Determination Of Adolescent Worldview-Combating Negative Influence Of Social Media. Jurnal Komunikasi Ikatan Sarjana Komunikasi Indonesia, 2(1), 6-19. 